\title{
The Transmission Channels between Financial Sector and Real Economy in Light of the Current Financial Crisis a Critical Survey of the Literature
}

\author{
Georgios L. Vousinas \\ Department of Economics, Athens University, Athens, Greece \\ Email: vousinas@yahoo.com
}

Received June 26, 2012; revised July 26, 2012; accepted April 26, 2013

Copyright (C) 2013 Georgios L. Vousinas. This is an open access article distributed under the Creative Commons Attribution License, which permits unrestricted use, distribution, and reproduction in any medium, provided the original work is properly cited.

\begin{abstract}
The present study undertakes a critical review of the research around the major issue of the transmission channels between financial sector and real economy. The aim of the study is to shed light on the interaction between the financial system and the economy, in the shadow of the current crisis. The literature documents the importance of these channels in the determination of economic activity and therefore, real economy as a whole. The study highlights the emergence of the liquidity channel as a key factor of the transmission of bank credit shocks to real economy and underlines the existing "regulation gaps". The paper concludes that the financial sector plays an even more crucial role these days and drastic measures along with intense supervision must be undertaken so as to work properly and serve the economic world.
\end{abstract}

Keywords: Transmission Channels; Bank Lending Channel; Financial Crisis; Regulation; Liquidity

\section{Introduction}

This literature review considers transmission channels between real and financial sector that potentially operate in both directions. Specifically, financial conditions are affected by the conditions in the real economy and in particular, households' and (financial and nonfinancial) firms' balance sheets and the conditions of households' and firms' balance sheets eventually affect real economic activity. The theoretical research on the linkages between the real and the financial sector is dominated by classic macroeconomic theory. Specifically, weaker macroeconomic conditions reduce the revenues and profits of businesses (including banks) and the incomes of households, which results in households' and businesses' net worth increasing more slowly or in some cases even decreasing. An additional implication of reduced business revenues and household profits is that it increases borrower default probabilities, which in turn affects bank losses and thereby bank balance sheets. The theoretical literature on the linkage that runs from the financial to the real sector represents the lion's share of the literature on real and financial sector transmission channels. At this point it must be highlighted that the interactions that exist between financial variables (such as interest rates) and real variables (such as consumption or investment), which arise purely from the intertemporal aspect of households' and firms' spending decisions - rather than as a result of any financial friction-do not constitute a financial and real sector transmission channel. For example, the permanent income model of consumption notes the relevance of the discounted value of a household's stream of future income in determining its current consumption. Because the appropriate discount factor for future income is the real interest rate, this results in the real interest rate, a nominally financial variable, influencing consumption. Similarly, in the neoclassical investment model, interest rates affect spending decisions because they represent the relevant variable for discounting future flows of capital rental income and/or depreciation allowances. It is important to note, however, that although these financial variables influence real activity in standard macro models of consumption and investment, there is no more than a trivial role for the financial sector. Indeed, the financial sector in these models serves only to transfer income across time; and it performs this role perfectly, without facing any of the financial frictions that in practice exist in the intermediation of credit. In studying the real and financial sector transmission channels, the major interests 
lie in understanding how informational asymmetries, incomplete markets, agency costs and costly contract enforcement, in conjunction with the financial sector's attempts to overcome these problems, influence the interactions between key financial and real sector decision variables that are absent from a standard, full-information, neoclassical model. This study reviews the existing literature that deals with these financial and real sector interactions. According to the theoretical literature, three channels have been identified to account for the transmission of shocks originating in the financial sector to the real economy and the amplification and retransmission, via the financial sector, of shocks originating in the real economy. The three channels, which broadly relate to the overall asset and liability position of either banks or their borrowers, are: 1) the borrower balance sheet channel; 2) the bank balance sheet channel; and 3) the liquidity channel. The following Figure 1 summarizes the research findings through the identification of the aforementioned transmission channels.

The first two channels, which are often referred to as the financial accelerator [1], challenge the ModiglianiMiller view of the irrelevance of financing for a firm's (or for a bank's) investment decision. The borrower balance sheet channel and aspects of the bank balance sheet channel emphasise the influence of the net-worth or equity position of the borrower or bank on the credit conditions these agents face. Both balance sheet channels can arise as a result of capital-market frictions - such as information asymmetries, problems in contract enforcement and agency costs, while a specific bank balance sheet channel can also arise for banks as a result of regulatory requirements on bank capital. The third channel

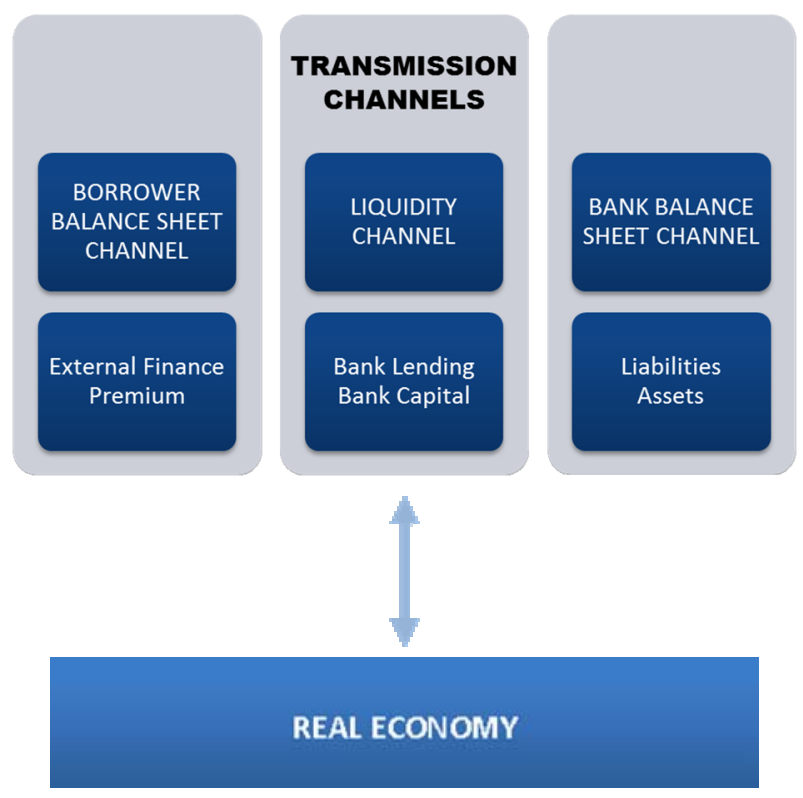

Figure 1. Table of research findings. emphasises the liquidity position of balance sheets and highlights the rigidities that can be present (either in all circumstances or at times of extreme stress) in altering balance sheet variables. These rigidities in turn then affect real economic variables. Interest in this channel has been fairly recent-in part, spurred on by the current crisis, and to date has been addressed for the most part in the context of banks.

\section{The Borrower Balance Sheet Channel}

The borrower balance sheet channel, which applies to both firms and households, stems from the inability of lenders

- to assess fully borrowers' risks and solvency

- to monitor fully their investments

- to enforce fully their repayment of debt

This leads lenders to require specific collateral for borrowing, which in fact means that the equity position of the borrower influences their access to credit funds. There are two broad classes of borrower balance sheet models in the literature. In the first class of models, which is associated with Bernanke and Gertler [2] and Carlstrom and Fuerst (1997), borrowers face an "external finance premium", which refers to a positive wedge between the costs of externally and internally raised funds. This wedge typically depends inversely on borrowers' creditworthiness. This means that the worst the solvency of the borrower the bigger the premium required and inversely, which in turn is tied to borrowers' net worth. The external finance premium arises from the fact that borrowers have an incentive to take on greater amounts of risk than are in lenders' interest, and lenders have limited means in order to restrict the amounts of risk that borrowers desire. Involving borrower net worth in the financing of a project is, however, one way to align more closely the risk-taking incentives of borrowers and lenders since doing so means that borrowers, along with lenders, will face similar losses in case of a project failure. Thus, the greater the net worth of the borrower, the lower is the premium required by the lender. This means that any kind of shock that affects net worth (such as a financial shock or a shock to aggregate demand that weakens firm profits and household income and in turn net worth) will affect the borrower's cost of financing, which (via standard user-cost or interest rate channels) will then affect the volume of expenditures that borrowers ultimately desire to undertake and thereby aggregate demand. Net worth is affected by shocks to aggregate demand and the real economy, which means that the presence and the properties of the external finance premium serve to propagate shocks to the real economy and amplify business-cycle fluctuations, hence the channel's name, the financial accelerator. In addition, financial shocks, such as fluctuations in asset prices also affect borrower 
net worth, which means that the external financial premium also transmits financial shocks to the real economy. The second class of borrower balance sheet or financial accelerator model is associated with the work of Kiyotaki and Moore [3]. In this model, assets play a dual role in the economy, in that they are used to produce goods and services and to provide collateral for loans. The need for collateral in these models arises from the fact that lenders cannot force borrowers to repay their debts unless the latter are secured. These problems of debt-contract implementation create interactions between credit limits and asset prices through both a static, within-period multiplier and a dynamic, inter-temporal multiplier. Any financial shock leading to a fall in asset prices will tighten the collateral constraint, which in turn lowers production and spending and depresses asset prices farther. Note also that because reduced production and spending stemming from shocks to the real sector also depress asset prices, shocks to the real economy can also be propagated via this mechanism. Borrower collateral also plays a key role in Holmström and Tirole's [4] financial accelerator model, which allows for both intermediated credit (offered by banks) and non-intermediated credit (offered by investors). In this model, non-intermediated credit is less costly for borrowers, because it does not involve any monitoring, although it requires that greater collateral be offered by borrowers. If borrowers have insufficient collateral to obtain non-intermediated credit from investors, they must obtain credit from banks. This lending requires costly monitoring, which up to some point banks recoup by charging a higher cost of funds to borrowers. However, banks also have limited capital, which places a limit on their ability to monitor, so that borrowers with very low collateral are unable to obtain any type of credit. Adverse shocks to borrower collateral, which Holmström and Tirole call a "collateral squeeze", produce higher funding costs along with some borrowers failing to obtain credit, where the effects are most severe for poorly capitalised borrowers. Both of these effects restrain expenditure and result in lower aggregate demand.

\section{The Bank Balance Sheet Channel}

The bank balance sheet channel can be divided into two separate components: the traditional bank lending channel and the bank capital channel. Both channels recognise that adverse shocks to financial institutions' balance sheets, which may arise from changes in monetary and regulatory policy or bank capital losses, can entail sharp contractions in credit and result in such shocks having magnified effects on economic activity. One condition necessary for such amplified effects to occur is for some borrowers to be highly dependent on banks for credit. This dependence implies that if the supply of bank loans is severely disrupted, these borrowers, while not com- pletely cut-off from credit, face indeed sizable difficulties and costs in finding and forming relationships with new lenders, and these results in these borrowers having to curtail their expenditures. Another condition that causes adverse bank balance sheet shocks to have amplified effects on economic activity is the inability of banks to fully insulate their supply of lending in response to such shocks. In the traditional bank-lending channel framework, monetary policy shocks have effects on the cost and availability of credit which go beyond the traditional effect through interest rates. In particular, when the latter of the two above conditions is met, both sides of banks' balance sheets contract in response to a negative monetary shock. On the liability side, a monetary policy tightening decreases money supply and money demand, which is the standard effect of monetary policy. On the asset side, it entails a change in the asset composition, leading to a stronger decline in credit supply, which is the lending channel [5]. Moreover, through the condition of high dependence on banks for credit, borrowers must reduce their real spending after a tightening in credit conditions by banks. This analysis can also be applied to other types of shocks such as bank capital losses. Recent developments in financial markets, most notably the emergence of private securitisation markets, have raised the question of whether the dramatic growth in securitisation has diminished the importance of the bank lending channel. For example, Nwogugu (2007) considers the interactions between capital reserve requirements and securitisation and shows that from a theoretical perspective the latter undermines the ability of the central bank's reserve requirements to limit the expansion of credit by commercial banks. The models discussed above assume that banks hold no capital and are entirely funded by external liabilities. Furthermore, there is no endogenous credit risk in these models (all loans are paid back), and so there is no room to analyse regulatory policy. Other models analyse why changes in banks' capital levels, which can arise for a number of reasons, influence the volume of loans that banks can extend, the bank capital channel. In Holmström and Tirole's [4] financial accelerator model, all bank lending is financed by capital, which provides the incentive for banks to monitor borrowers, and thereby overcome the moral-hazard problems present in borrowers' investment decisions. Consequently, a capital crunch will result in banks providing less credit to borrowers, where as was also the case with an adverse shock Another reason, noted by Stein [6], as to why bank capital can affect lending is directly analogous to the financial accelerator model discussed in the previous section, albeit for banks rather than households or firms. Specifically, the cost and availability of non-deposit funds for any given bank will depend on the perceived creditworthiness of the institution, which, like the borrower bal- 
ance sheet model, is tied to bank capital. Intuitively, better capitalised banks are perceived to have stronger incentives to carefully underwrite and monitor loans and as a result are able to attract nondeposit funding at a lower cost. This implies that an external finance premium that depends negatively on bank capital is present for banks' non-insured financing. Since the external finance premium paid by banks is in turn reflected in the cost and availability of funds to bank-dependent borrowers a reduction in bank capital increases the cost of funds faced by banks and the cost of funds faced by borrowers and thereby constrains economic activity. As discussed by Van den Heuvel [7], a further reason why bank capital can affect lending stems from regulatory requirements. That is, due to regulatory capital requirements a bank's holding of capital places an upper bound on bank assets and thereby bank lending. Importantly, there are two conditions required for the bank capital channel to operate. First, banks should have no excess capital that can be used to buffer against shocks that deplete bank capital. And, second, the capital market is imperfect in that it is costly for a bank to raise capital. Any shock-financial or real that adversely affects bank capital will reduce banks' ability to extend credit, which in turn will restrain the volume of expenditures that the banks' borrowers can ultimately undertake. Shocks to aggregate demand, as well as conditions in real estate markets, may influence loan losses and, if not buffered by profits, can affect bank capital. In addition, changes in interest rates as well as changes to the slope of the yield curve, because they affect real activity and bank profits, can also affect bank capital. Van den Heuvel highlights the cushioning effect that above regulatory levels of bank capital have on this channel. In particular, he develops a dynamic model of bank asset and liability management in which interest rate shocks have a more delayed and amplified effect on lending by banks with depleted capital relative to banks that are well capitalised. That said bank capital is shown to affect lending even when the regulatory constraint is not momentarily binding, which implies that shocks to bank profits, such as loan defaults, can have a persistent impact on lending. Note also that financial sector shocks such as fluctuations in asset prices also affect banks' capital, which means that the bank capital channel also transmits financial shocks to the real economy. Basel II capital requirements have the potential to further exacerbate the effects of bank capital on lending and this has been a major source of concern in discussions on the impact of the revised regulatory framework for capital adequacy. As Lowe [8], Borio et al. [9], Altman and Saunders [10], and Goodhart et al. [11] all note, not only do worsening economic conditions deteriorate the actual bank capital ratio via the effect of loan losses on bank capital but in addition risk-weighted assets also rise. This is because in downturns, credit risk, as measured by the borrower's probability of default (PD), loss-given-default (LGD) and exposure at default (EAD), typically increases thereby also increasing capital requirements, which under the Basel II framework are more closely tied to risk than under a "flat-rate" capital requirements framework, such as Basel I. Banks would therefore face much higher capital needs, while finding it more difficult to increase their capital because their profits and hence their capacity to build up reserves diminishes. Faced with these difficulties in raising new equity, banks would likely then de-lever their assets and reduce certain types of their assets - such as lending — which have higher risk weights. This would imply a reduction in the amount of credit extended to firms and households, which could in turn worsen the initial economic downturn. Conversely, during an economic upturn, banks holding excess capital would face much lower capital needs, expand credit further and fuel a credit-led boom. At present, this literature is largely empirical or simulation-based, although Jacques [12] presents a theoretical model that produces procyclical capital outcomes. The most common statistical model used by the literature for the examination of time series data, is the Vector Autoregressive (VAR) model. The VAR model has proven to be especially useful for describing the dynamic behavior of economic and financial time series and for forecasting.

\section{The Liquidity Channel}

The ongoing financial crisis has highlighted the importance of liquidity as an influence on banks' ability to extend credit and thereby on economic activity. In some cases, liquidity conditions merely influence the strength of existing real and financial sector transmission channels. In other cases, however, liquidity considerations create additional real and financial sector transmission channels. This point has long been established, although the recent crisis has led to an increased focus on these types of channels. High leverage ratios and large maturity mismatches in banks' balance sheets are a critical element in the propagation of funding liquidity shocks to bank lending and the real economy. Indeed these features of bank balance sheets and the adverse asset price spirals that they can engender were noted as early as Fisher [13], who described the strong links between distressed asset sales and banks' health. The basic mechanism is that given a liquidity or solvency shock, banks start to sell assets, which creates excess supply in asset markets and lowers asset prices. Falling asset prices in turn imply further asset sales (so as to meet resulting margin calls), which in turn means that a downward spiral in asset prices and balance sheet health sets in Diamond and Dybvig [14], in their seminal work on bank runs, also 
noted this mechanism while, more recently, Diamond and Rajan [15] stress the interaction and reinforcing effects of banks' liquidity shortages and solvency problems. Noting that because banks finance illiquid assets with short-term debt, Diamond and Rajan explain how aggregate liquidity shortages can emerge, such that if depositors (or liability holders more generally) unexpectedly demand payments (or are unwilling to roll over debt), banks can be forced to prematurely foreclose otherwise profitable loans. This can result in banks' facing sizable losses that will restrain future lending and at the extreme can drive contagious bank failures. In light of the current crisis, the literature has made the distinction between two types of liquidity: funding liquidity and market liquidity. Funding liquidity refers to the liability side of banks' balance sheets and can be defined as an institution's ability to get funding immediately, through asset sales or new borrowing, in order to meet payment obligations on debt at maturity. On the other hand, market liquidity refers to the asset side of banks' balance sheets and defines the ease with which an asset can be traded. In Diamond and Rajan, the presence of both funding and market liquidity can result in the anticipation of funding liquidity shortages inducing even healthy (i.e. liquidity ample) banks to refrain from lending. This occurs because the expectation of distressed banks being forced to sell (somewhat illiquid) assets in the future at fire-sale prices drives healthy banks to hoard liquid funds so as to allow them to take advantage of future investment opportunities. This mechanism appears to have been at work during the last financial market crisis. The presence of both funding and market illiquidity is an important feature of Brunnermeier and Pedersen [16]. These authors develop a formal model that links the market liquidity of a security and the funding liquidity of traders. The providers of market liquidity are traders - specifically, market makers, banks' proprietary traders and hedge funds - that act as intermediaries by buying and selling securities. In practice, the funding of traders impacts market liquidity and is itself also impacted by market liquidity, because traders are subject to funding constraints on their trading. In the model, funding liquidity risk is the risk of a binding funding constraint, which stems from the requirement that a trader must be able to finance all of his or her security positions at any point in time. While there are some differences in the definition of capital across the three major types of traders, the basic funding constraint is that total capital use must be smaller than the available net capital available plus available debt funding. When dealer capital is abundant, market liquidity is at its highest level and insensitive to marginal changes in capital and margins [7]. In contrast, when funding liquidity is scarce, traders become hesitant to acquire positions, especially capital-intensive positions that require high mar- gins. As a result, market liquidity is lower. Moreover, low future market liquidity can increase the risk of financing trades, thus increasing margins. There are multiple competitive equilibriums in Brunnermeier and Pedersen's model under the (necessary and sufficient) condition that decreased market liquidity leads to either higher margin requirements or losses on dealers' existing positions. In the "liquid" equilibrium, markets are liquid, which leads to favourable margin requirements for dealers, which consequently helps dealers make markets liquid. In the "illiquid" equilibrium, markets are illiquid, resulting in larger margin requirements (or dealer losses), thereby restricting dealers from providing market liquidity. Once in this equilibrium, market liquidity becomes very sensitive to shocks due to two amplification mechanisms, so-called "liquidity spirals": the margin spiral and the loss spiral. During crises, decreases in market liquidity and funding liquidity are mutually reinforcing and produce either margin spirals or loss spirals. Margin spirals occur in the following way. A decrease in funding compels a dealer to provide less market liquidity. If margins increase as market liquidity decreases, the initial decline in funding tightens the dealers' funding constraint further, which in turn forces them to diminish their trading and so on, leading to a margin spiral. Loss spirals (asset price spillovers) occur along similar lines. The model explains the empirically documented features that market liquidity: 1) can suddenly dry up (i.e. is fragile); 2) has commonality (is correlated) across securities; 3) is related to volatility; 4) experiences flight to liquidity events; and 5) co-moves with the market. Cifuentes, Ferrucci and Shin (2005) show that mark to market accounting may turn out to be a channel for contagion and systemic risk. They analyse mark to market accounting in a model with regulatory solvency requirements and internal risk controls of banks. When a shock in the market reduces the market value of banks' assets, banks may be forced to sell parts of their assets in order to satisfy regulatory solvency requirements and/or internal risk limits. This causes market prices, and hence the market values of banks' assets, to decrease further when markets cannot perfectly absorb asset sales. The authors show that regulatory minimum liquidity requirements can mitigate this mechanism and hence also systemic risk. Wagner $[17,18]$ explores the implication of a lack of market liquidity in times of stress. On the one hand, a lack of market liquidity implies that asset sales to meet liquidity demands lower asset prices even further, which can lead to the failure of other institutions. On the other hand, low market liquidity increases the cost of failure for individual firms, the more so, the larger the number of banks that fail. Hence, a bank's returns, as well as the negative externalities arising when it fails, will depend on the entire return distribution of the other banks' portfolios. An op- 
timal regulatory regime has to take this into account and banks which are more correlated with each other should face higher capital and/or liquidity requirements. At the margin, commercial and universal banks expand and contract their balance sheets by borrowing in the repo market and in unsecured money markets. Such expansion and contraction of balance sheets is primarily constrained by regulation and credit-rating considerations. For example, when the haircut on AAA-rated mortgages is 5\%, an intermediary can obtain a leverage of $20: 1$. When haircuts increase to $20 \%$, the intermediary is forced to unwind as leverage has to drop to 5:1. Adrian and Shin [19] provide a micro foundation for the determination of total leverage. In a macro-setting, Kiyotaki and Moore provide a general equilibrium analysis of the value of assets as collateral. The interlinkages between funding liquidity and market liquidity can become a crisis-propagation channel in the presence of incomplete markets and asymmetric information. This is because in the face of such interlinkages, the absence of a complete set of contingent securities (which implies that it is not possible to hedge against future liquidity outcomes) combined with information asymmetries about the solvency of the banks (which implies that it is not possible to distinguish whether a bank is illiquid or insolvent), may stimulate fears of counterparty credit risk [20-22] belong to this literature. Another important topic concerning the liquidity channel is the relationship between the use of leverage by institutions and liquidity problems. Gromb and Vayanos [23] model financial market liquidity as provided by financially constrained arbitrageurs. They show that arbitrageurs, who depend on external capital (the so called "smart money") and undertake leveraged transactions, provide liquidity to the market and also cause liquidity dry-ups. Market liquidity increases with the level of arbitrage capital (that is, internal money), as well as external "smart money" that arbitrageurs can access frictionlessly. They show that liquidity dry-ups follow periods of low returns for arbitrageurs' risky investment opportunities and that liquidity is correlated across markets. Their welfare analysis shows that arbitrageurs may fail to take socially optimal positions (social welfare) in their investments, thereby adversely affecting their ability to provide market liquidity. This liquidity channel arises from their failing to internalise the price effects of their investment decisions. Acharya and Viswanathan [24] propose a model that explains the deleveraging phenomenon observed in the current crisis in terms of the agency problem confronted by leveraged institutions. They consider a moral hazard setup wherein leveraged institutions have incentives to take on excessive risks and are thus rationed when they attempt to roll over their debt. Institutions can sell assets to alleviate rationing. Liquidated assets are purchased by non-rationed institutions but their borrowing capacity is also limited by the same principal-agent relationship. The market-clearing or liquidation price exhibits cash-in-the-market pricing. When a large number of firms are liquidating assets, the market price will be below the expected discounted cash flow and asset prices will thus depend on the entire distribution of leverage in the economy. The distribution of leverage and its form as rolled-over debt is derived endogenously, with each institution's choice of leverage affecting the difficulty of other institutions in rolling over their debt in the future. The model provides an agency-theoretic linkage between market liquidity and funding liquidity and formalises the deleveraging of financial institutions observed during crises. It also explains the role played by system-wide leverage in generating deep discounts in prices when adverse asset-quality shocks occur following a period of good times. Adrian and Shin point out another new feature of the current economic crisis, namely, that securitisation increased the importance of brokerdealers in the credit supply chain. They note that the growth of leveraged financial intermediaries that mark to market synchronises responses and increases feedback effects on the real economy. Financial stress may make it difficult to raise equity, in which case reducing leverage becomes synonymous with asset disposal. Increases in interest rate shocks or declines in asset prices can instigate the deleveraging cycle. Adrian and Shin also argue that because their liabilities are short-term, broker-dealers give a better signal of marginal funding conditions than commercial banks. Their findings also suggest that changes in the balance sheets of security broker-dealers help explain future real activity, especially for housing investment and durable goods consumption that are sensitive to credit supply. They find that the presence of broker-dealers leads to a faster and larger drop in housing investment in response to a Fed funds target increase, but also a quicker recovery. With their results in mind, one of the implications of the disappearance or conversion of all five major independent investment banks in the autumn of 2008 is that it signalled the severity of the approaching real sector storm, but also that their absence from the market could lengthen the time to recovery.

\section{Conclusions}

As perceived by the aforementioned, the meaningful issue of the transmission channels between financial sector and real economy stands in the foremost of the scientific attention over the last years and especially during the current financial crisis. The research literature has recognized three major channels concerning the transmission of shocks between financial sector and real economy, focusing on the two sides of balance sheets, assets and liabilities. These are the borrower balance sheet channel, 
the bank balance sheet channel and the newly liquidity channel.

The emergence of the liquidity channel in times of economic recession as a key term in the equation of the transmission channels, has given food for extensive research and analysis in order to shed light on its shadow areas. The findings so far concentrate exclusively on banks but it is crucial for the research to deal with the non-bank systemic financial institutions whose failure have a large impact on the broad financial system and therefore on banks' ability to lend. This paper notes significant changes in the functioning of the bank lending channel due to financial innovation and changes in banks' business models. In comparison to earlier evidence, the paper documents that the standard bank-specific characteristics usually included in the literature (such as size, liquidity, capitalization) are not able to fully capture the functioning of the new dimensions of the bank lending channel. An important result is that the type of funding is a key element to assess banks' ability to withstand adverse shocks: short-term funding and securitisation activity seem to be particularly important in this respect. The amount of investment banking and other fee-based activities is also a relevant factor influencing the transmission mechanism. Banks with a high amount of more profitable but also more volatile non-interest income activities supplied more lending prior to the crisis but also limited credit to borrowers by more during the crisis. These results also hold when we account for weak supervision of financial activities by regulators. An important question in this respect is whether such changes in the transmission mechanism will remain in the near future or will tend to disappear as the crisis subsides. The functioning of the monetary transmission mechanism will be influenced by future developments in the securitization and regulation of financial intermediaries. For example, a dry-up in the securitization market will affect banks' possibilities to raise funds from the financial market and hamper their ability to respond to changes in loan demand in case of a monetary tightening. The bank lending channel will also be influenced by tighter regulation within the bounds of the new global regulatory standard by the Basel Committee on Banking Supervision (Basel III), that strengthen bank capital requirements and introduce new regulatory requirements on bank liquidity and bank leverage. A very important measure in this way is the introduction of Net Stable Funding Ratio, which is a global minimum liquidity standard for internationally active banks that includes a 30-day liquidity coverage ratio requirement underpinned by a longer-term structural liquidity ratio. Higher minimum capital and liquidity requirements, such as the above, will at least in the short-term, increase banks' funding costs thereby reducing their credit supply. By harnessing banks' capital and liquidity positions, the new financial regulations are also likely to shore up banks' soundness lowering banks' risk premium as required by financial markets' investors on their long-term debt funding. While it is difficult to measure accurately the net benefit of new financial regulations, their impact on banks' profitability and cost of funding will have for sure an effect in the functioning of the bank lending channel in the years to come. Some very important conclusions can be derived from the paper. First of all, the stronger effectiveness of monetary policy detected during the crisis period has to be considered temporary against the backdrop of two concurrent factors: low interest rates and the use of unconventional monetary policy. Very low interest rates, close to the zero bound can be deemed a concern as they create distortions in the allocation of savings and investments. Under specific circumstances they can also raise the macroeconomic risks of approaching a deflationary trap $[25,26]$. The use of unconventional monetary policies aims at improving the impact of systemic risks in financial markets and provisional in nature. On the contrary, a prolonged period of excessive liquidity could distort manager decisions on long-term projects that are highly sensitive to interest rates. Indeed, the recent experience in Japan has illustrated how low policy rates contributed to "ever-greening" policies i.e. the roll over of non-viable loans [27]. Similarly, an asymmetric monetary policy response of cutting rates sharply when the economy is in trouble and not raising them quickly enough when it recovers gives the financial sector fewer incentives to worry about future credit or liquidity risks causing a classic moral hazard problem. Another policy implication is that monetary policy is not fully neutral from a financial stability perspective. Deregulation and financial innovation have made banks much more dynamic and probably more subject to market conditions and financial instability bouts. From a policy perspective, this is bringing financial stability and monetary policy considerations much closer to one another particularly when compared to the past decade. Finally, from an operative perspective, the undoubtedly strong impact of banks' conditions in determining their loan supply calls for extending the statistical coverage and analysis of the banking sector by central banks. This would include detailed standardised and comparable microeconomic balance-sheet information on individual banks matched with borrowers' conditions (i.e. including banks' lending terms and conditions to individual borrowers). A very useful initiative in this respect would be the creation of comprehensive and standardised credit registers available to central bankers on a confidential basis. It would also incorporate a comprehensive coverage of banks' off-balance-sheet activities, which could better capture changing business models and financial innovation developments [28,29]. Dif- 
ference in data protection laws could be however a difficult obstacle to overcome [30]. Furthermore, the closer link between financial stability and monetary policy considerations would call for a better knowledge of banks' incentives towards risk-taking. The systemic dimension of risk-taking could have a macroeconomic impact on the aggregate loan supply. It would also call for a widening of the perimeter of statistical data collection to include the incentives of non-bank systemic financial institutions whose failure could potentially have a large impact on the broad financial system and therefore on banks' ability to lend. All in all this calls for a more forward-looking and dynamic approach towards data collection by central banks, supervisory authorities and statistical offices in a way that risk-taking incentives of large financial players are better understood. The recent crisis has prompted the creation of a number of institutions in charge of monitoring and containing the emergence of systemic risks in a number of countries. The coordination of the collection and analysing of the type of data mentioned earlier in close cooperation with central banks would be useful for a careful quantification of bank supply constraints. More broadly this cooperation might be paramount for ascertaining an optimal policy action to prevent or buffer future financial crisis. At this point and following the above, it's considered necessary to share some thoughts about certain aspects of the current financial crisis. Specifically, the interest lies in two major questions: Why is it so important for the central banks to intervene? And what is the extent to which deregulation caused the current credit crunch? In response, the following answers are provided: The principal reason the central banks needed to intervene was to minimize the damage caused by a credit crunch and prevent the expansion of the financial crisis. In the author's view, they failed in both ways coming to the conclusion that deregulation was a major factor for the credit crunch. The supervision was inadequate due to the fact that relied excessively on the rating agencies (Fitch, Moody's and S\&P) as a benchmark and avoided systematically the intervention in markets in the name of consumer protection and the "free market". The authorities also failed to follow the financial innovations of the banking system with new entered products such as securitization, the evolution of CDS market and new lending technologies. In this direction, another important question arises on whether the regulatory structure should be extensively reorganized to meet with the new established standards. The current structure, which gives considerable authority to central banks, may still be the best model according to the author's opinion. Specifically, important synergies are developed in giving the authority for prudential supervision of banks, for consumer protection, for monetary policy and above all, for ensuring general financial stability. In this regard, it might be better to focus on improving the central banks' future performance rather than restructuring the entire regulatory structure of our modern financial system, with attention to the analysis of systemic risks and the use of proper data. So it's in the authorities' hands to monitor the financial and banking conditions and intervene to the extent that every time is needed so as to ensure the proper functioning of the transmission channels and guarantee the systemic cash flows avoiding liquidity traps. Concluding, it is of major importance for the global financial system to confront to the same rules through common target policies of the central banks across the universe. The top economies of the world currently have different policies regarding the objectives of their regulation systems due to many reasons, but the financial crisis of our times has underlined the "chain effects" of shocks and proved that combined actions should be undertaken to prevent such situations. The authorities have to obey the same rules and that is a matter of strong political will and cooperation of the G-20 countries and the world organizations such as OECD and IIF, so as the economic system to work properly and in favor of the social welfare.

\section{REFERENCES}

[1] B. S. Bernanke and M. Gertler, "Inside the Black Box: The Credit Channel of Monetary Policy Transmission," Journal of Economic Perspectives, Vol. 9, No. 4, 1995, pp. 27-48. doi:10.1257/jep.9.4.27

[2] B. S. Bernanke and M. Gertler, "Agency Costs, Net Worth, and Business Fluctuations," American Economic Review, Vol. 79, No. 1, 1989, pp. 14-31.

[3] N. Kiyotaki and J. Moore, "Credit Cycles," Journal of Political Economy, Vol. 105, No. 2, 1997, pp. 211-248. doi:10.1086/262072

[4] B. Holmström and J. Tirole, "Financial Intermediation, Loanable Funds, and the Real Sector," Quarterly Journal of Economics, Vol. 112, No. 3, 1997, pp. 663-691. doi:10.1162/003355397555316

[5] B. S. Bernanke and A. S. Blinder, "Credit, Money, and Aggregate Demand," American Economic Review, Vol. 78, No. 2, 1988, pp. 435-439.

[6] J. C. Stein, “An Adverse-Selection Model of Bank Asset and Liability Management with Implications for the Transmission of Monetary Policy," RAND Journal of Economics, Vol. 29, No. 3, 1998, pp. 466-486. doi: $10.2307 / 2556100$

[7] S. J. Van den Heuvel, "Does Bank Capital Matter for Monetary Transmission?" Federal Reserve Bank of New York Economic Policy Review, Vol. 8, No. 1, 2002, pp 259-265.

[8] P. Lowe, "Credit Risk Measurement and Procyclicality," BIS Working Paper, No. 116, Basel, 2002.

[9] C. E. V. Borio, C. Furfine and P. W. Lowe, "Procyclicality of the Financial System and Financial Stability: Issues and Policy Options,” BIS Working Paper, No. 1, Basel, 
2001.

[10] E. I. Altman and A. Saunders, "An Analysis and Critique of the BIS Proposal on Capital Adequacy and Ratings," Journal of Banking and Finance, Vol. 25, No. 1, 2001, pp. 25-46. doi:10.1016/S0378-4266(00)00116-3

[11] C. A. E. Goodhart, B. Hofmann and M. Segoviano, "Bank Regulation and Macroeconomic Fluctuations," Oxford Review of Economic Policy, Vol. 20, No. 4, 2004, pp. 591-615. doi:10.1093/oxrep/grh034

[12] K. T. Jacques, "Capital Shocks, Bank Asset Allocation, and the Revised Basel Accord," Review of Financial Economics, Vol. 17, No. 2, 2008, pp. 79-91. doi:10.1016/j.rfe.2007.03.003

[13] I. Fisher, "The Debt-Deflation Theory of Great Depressions," Econometrica, Vol. 1, No. 4, 1933, pp. 337-357. doi: $10.2307 / 1907327$

[14] D. W. Diamond and P. H. Dybvig, "Bank Runs, Deposit Insurance, and Liquidity," Journal of Political Economy, Vol. 91, No. 3, 1983, pp. 401-419. doi:10.1086/261155

[15] D. W. Diamond and R. G. Rajan, "The Credit Crisis: Conjectures about Causes and Remedies," American Economic Review, Vol. 99, No. 2, 2009, pp. 606-610. doi:10.1257/aer.99.2.606

[16] M. K. Brunnermeier and L. H. Pedersen, "Market Liquidity and Funding Liquidity," NBER Working Papers, No. 12939, 2007.

[17] W. Wagner, "Diversification at Financial Institutions and Systemic Crises," Tilburg University Center for Economic Research Discussion Paper, No. 71, 2006.

[18] W. Wagner, "The Homogenization of the Financial System and Financial Crises," Journal of Financial Intermediation, Vol. 17, No. 3, 2008, pp. 330-356. doi:10.1016/j.jfi.2008.01.001

[19] T. Adrian and H. S. Shin, "Liquidity and Financial Contagion," Banque de France Financial Stability Review, No. 11, 2008, pp. 1-8.
[20] F. Allen and D. Gale, "Financial Contagion," Journal of Political Economy, Vol. 108, No. 1, 2000, pp. 1-33. doi:10.1086/262109

[21] S. Brusco and F. Castiglionesi, "Liquidity Coinsurance, Moral Hazard, and Financial Contagion," Journal of Finance, Vol. 62, No. 5, 2007, pp. 2275-2302. doi:10.1111/j.1540-6261.2007.01275.x

[22] P. Strahan, "Liquidity Production in 21st Century Banking”, NBER Working Papers, No. 13798, 2008.

[23] D. Gromb and D. Vayanos, "Leverage and Liquidity DryUps: A Framework and Policy Implications," 2008.

[24] V. V. Acharya and S. Viswanathan, "Moral Hazard, Collateral and Liquidity," Centre for Economic Policy Research, 2008.

[25] O. Jeanne and L. E. O. Svensson, "Credible Commitment to Optimal Escape from a Liquidity Trap: The Role of the Balance Sheet of an Independent Central Bank," American Economic Review, Vol. 97, No. 1, 2007, pp. 474-490. doi:10.1257/aer.97.1.474

[26] J. Bullard, "Seven Faces of the Peril," Federal Reserve Bank of St. Louis Review, Vol. 92, No. 5, 2010, pp. 339352

[27] R. J. Caballero, T. Hoshi and A. K. Kashyap, "Zombie Lending and Depressed Restructuring in Japan," American Economic Review, Vol. 98, No. 5, 2008, pp. 19431977. doi:10.1257/aer.98.5.1943

[28] T. Jappelli and M. Pagano, "Information Sharing in Credit Markets," Journal of Finance, Vol. 48, No. 5, 1993, pp. 1693-1718. doi:10.2307/2329064

[29] T. Jappelli and M. Pagano, "Information Sharing, Lending and Defaults: Cross-Country Evidence," Journal of Banking and Finance, Vol. 26, No. 10, 2002, pp. 2017 2045.

[30] A. Matuszyk and L. Thomas, "The Evolution of Credit Bureaus in European Countries," Journal of Financial Transformation, Vol. 23, 2008, pp. 135-144. 